\begin{tabular}{l|l} 
Potaice & e-ISSN: 2655-9404 p-ISSN: 2721-8376 \\
Vol. 5 No. 1, Februari 2022 & DOI: 10.20473/ntr.v5i1.33641 \\
\hline
\end{tabular}

Article history: Submitted 13 February 2022; Accepted 17 February 2022; Available online 24 February 2022.

\title{
Keabsahan Lelang Non Eksekusi Sukarela Secara Online Tanpa Pejabat Lelang
}

\author{
Vina Putri Salim dan Bambang Sugeng Ariadi Subagyono \\ vinaaputrii44@gmail.com \\ Universitas Airlangga
}

\begin{abstract}
Auction basically adopts the characteristics of a sale and purchase agreement (1457 BW), where the elements of price and goods are important elements. The difference is that auctions require the presence of an Auction Officer, especially for execution auctions and mandatory non-execution auctions. The auction has special regulations (Lex Specialis) namely Vendu Reglement, Vendu Instructie, and PMK 213/PMK.06/2020 concerning Auction Implementation Guidelines. The implementation of online auctions is carried out through the e-Marketplace Auction Platform where the implementation is usually carried out without an auction officer, for example auctions on eBay. The purpose of this study was to determine the validity of voluntary non-execution auctions conducted online without auction officer and protection for parties who suffered losses due to default. This research is a legal research with a statute approach, conceptual approach, and case approach. The results of the research are the validity of online voluntary non-execution auctions in the absence of an auction officer is valid by adopting the characteristics of a sale and purchase agreement. And for the legal protection, parties can take legal remedies for dispute resolution by choosing a settlement either through courts, arbitration or other alternative dispute resolution (conventionally/ online) in accordance with the provisions of the legislation.

Keywords: Online Auction; Default; Auction Officer.
\end{abstract}

Abstrak
Lelang pada dasarnya mengadopsi karakteristik dari perjanjian jual beli (1457 BW), dimana unsur harga dan barang merupakan unsur penting. Perbedaannya adalah pada lelang mengharuskan kehadiran seorang Pejabat Lelang, terutama untuk lelang eksekusi dan lelang non eksekusi wajib. Lelang memiliki peraturan khusus (Lex Specialis) yaitu Vendu Reglement dan Vendu Instructie sebagai peraturan lelang yang masih berlaku hingga saat ini. Selain itu pelaksanaan lelang juga diatur dalam PMK 213/PMK.06/2020 tentang Petunjuk Pelaksanaan Lelang. Pelaksanaan lelang secara online dilakukan melalui Platform e-Marketplace Auction dimana pelaksanaannya biasa dilakukan tanpa pejabat lelang, contohnya lelang di eBay. Tujuan penelitian ini adalah untuk mengetahui keabsahan lelang non eksekusi sukarela yang dilakukan secara online tanpa pejabat lelang dan bagaimana perlindungan bagi para pihak yang mengalami kerugian akibat wanprestasi. Penelitian ini merupakan penelitian hukum dengan pendekatan perundangundangan, pendekatan konseptual, dan pendekatan kasus. Hasil penelitian yang didapatkan adalah keabsahan lelang non eksekusi sukarela secara online tanpa adanya pejabat lelang adalah sah dengan mengadopsi karakteristik perjanjian jual beli. Dan perlindungan bagi para pihak adalah dengan melakukan upaya hukum penyelesaian sengketa dengan memilih penyelesaian baik melalui pengadilan, arbitrase ataupun lembaga penyelesaian sengketa alternatif lainnya (secara konvensional/ online dispute resolution) sesuai dengan ketentuan Peraturan Perundang-undangan.

Kata Kunci: Lelang Online; Wanprestasi; Pejabat Lelang. 


\section{Pendahuluan}

Seiring dengan majunya perkembangan zaman dan teknologi, pelaksanaan lelang juga ikut berkembang dari cara yang konvensional menjadi berbasis internet (online). Pelaksanaan lelang secara online menjadikan semuanya menjadi praktis, efektif dan efisien bagi para pihak yang ingin mengikuti lelang.

Pelaksanaan lelang melalui internet (online) secara implisit dapat dilihat pada ketentuan Pasal 1 angka 12 PMK 213/2020 tentang Petunjuk Pelaksanaan Lelang, yang menyebutkan bahwa: “Lelang tanpa kehadiran peserta adalah lelang yang tidak dihadiri secara fisik oleh peserta lelang di tempat pelaksanaan lelang atau dilakukan melalui aplikasi lelang atau Platform e-Marketplace Auction, hal ini memberikan makna secara bahwa pelaksanaan lelang dapat dilakukan juga melalui media internet atau secara online". Penggunaan Platform e-Marketplace Auction sebagai tempat untuk melaksanaan lelang secara online dinilai praktis, karena dapat dilakukan dimana saja dan dapat mengakomodir kebutuhan masyarakat, serta dapat meningkatkan perkembangan ekonomi. Adapun beberapa contoh e-Marketplace Auction yang ada di Indonesia antara lain : eBay (https:/ / ebay.blanja. com) dan E-Auction (www.lelang.go.id). ${ }^{1}$

Pasal 21 PMK 213/2020 menyebutkan bahwa, “setiap pelaksanaan lelang harus dilakukan oleh dan/ atau di hadapan Pejabat Lelang, kecuali ditentukan lain oleh Undang-Undang atau Peraturan Pemerintah". Akan tetapi, pada praktiknya, proses pelelangan secara online seperti di eBay dilakukan tanpa adanya pejabat lelang. Tugas pejabat lelang dalam pelaksanaan lelang non eksekusi sukarela ialah mengatur pelaksanaan lelang antara penjual dan pembeli, meskipun dilakukan secara online, ketentuan mengenai kelengkapan dokumen hingga uang jaminan lelang yang diberikan guna melindungi kepentingan para pihak, dilaksanakan oleh pejabat lelang. Pelaksanaan lelang yang dilakukan tanpa adanya pejabat lelang dapat berpotensi memunculkan peluang wanprestasi dari para peserta

${ }^{1}$ Margono Dwi Susilo dan Mirza Prasetya, 'Lelang dengan Platform e-Marketplace Auction Perbandingan antara eBay dan e-Auction (lelang.go.id)' (DJKN, 2019) < https:/ / www.djkn.kemenkeu. go.id/artikel/baca/12812/Lelang-dengan-Platform-e-Marketplace-Auction-Perbandingan-antaraeBay-dan-e-Auction-lelanggoid.html> diakses 7 Januari 2021. 
pelaksanaan lelang itu sendiri. Oleh karena itu, perlu dikaji mengenai keabsahan lelang non eksekusi sukarela yang dilakukan secara online tanpa pejabat lelang dan bagaimana perlindungan bagi para pihak yang mengalami kerugian akibat wanprestasi tersebut.

Dengan latar belakang di atas, maka dalam penelitian ini akan membahas mengenai keabsahan lelang non eksekusi sukarela secara online tanpa pejabat lelang dan bagaimana perlindungan hukum bagi para pihak yang mengalami kerugian akibat wanprestasi yang terjadi akibat lelang non eksekusi sukarela secara online tanpa pejabat lelang ini.

\section{Metode Penelitian}

Penelitian ini adalah penelitian hukum normatif, yaitu penelitian yang difokuskan untuk menganalisa suatu permasalahan hukum terhadap normanorma atau kaidah-kaidah hukum positif yang berlaku. ${ }^{2}$ Dan, pendekatan yang dilakukan adalah dengan pendekatan perundang-undangan (Statute Approach), pendekatan konsep (Conseptual Approach) serta pendekatan kasus (Case Approach).

Pendekatan perundang-undangan (Statute Approach) digunakan untuk menemukan aturan hukum untuk mengetahui keabsahan lelang non eksekusi sukarela secara online tanpa pejabat lelang dan perlindugan hukum bagi para pihak terkait. Pendekatan konseptual (Conceptual Approach) merupakan pendekatan yang beranjak dari pandangan-pandangan dan doktrin-doktrin yang berkembang dalam ilmu hukum guna menemukan ide-ide yang melahirkan pengertian, konsep dan asas hukum yang relevan sebagai sandaran dalam membangun suatu argumentasi hukum dalam memecahkan isu hukum yang dihadapi. ${ }^{3}$ Kemudian, pendekatan kasus (Case Approach) yaitu pendekatan dengan cara melakukan telaah terhadap kasus-kasus yang berkaitan dengan isu yang dihadapi yang telah menjadi putusan pengadilan yang telah mempunyai kekuatan hukum yang tetap. ${ }^{4}$

${ }^{2}$ Soerjono Soekanto dan Sri Mamudji, Penelitian Hukum Normatif (Suatu Tinjauan Singkat) (Rajawali Pers 2001).[13-14].

${ }^{3}$ Peter Mahmud Marzuki, Penelitian Hukum (Kencana Prenada Media Group 2016).[135-136].

${ }^{4}$ ibid.[134]. 
Pada penelitian ini akan dianalisa aturan-aturan hukum yang berkaitan dengan keabsahan pelaksanaan lelang non eksekusi sukarela secara online dan perlindungan hukum bagi para pihak yang melaksankannya.

\section{Tinjauan Umum Lelang dan Lelang Online.}

Pengertian Lelang berdasarkan ketentuan Pasal 1 angka 1 PMK 213/2020 tentang Petunjuk Pelaksanaan Lelang adalah "penjualan barang yang terbuka untuk umum dengan penawaran harga secara tertulis dan atau lisan yang semakin meningkat atau menurun untuk mencapai harga tertinggi yang didahului dengan pengumuman lelang".

M. Yahya Harahap memberikan definisi bahwa lelang merupakan penjualan dimuka umum yaitu pelelangan dan penjualan barang yang diadakan di muka umum dengan penawaran harga yang makin meningkat, dengan persetujuan harga yang makin meningkat atau dengan pendaftaran harga, atau dimana orang-orang yang diundang atau sebelumnya diberitahu tentang pelelangan atau penjualan atau kesempatan yang diberikan kepada orang-orang yang berlelang atau yang membeli untuk menawar harga, menyetujui harga atau mendaftarkan. ${ }^{5}$

Penjualan Lelang dikuasai oleh ketentuan-ketentuan dalam Burgerlijk Wetboek (selanjutnya disingkat "BW") mengenai jual beli yang diatur dalam Buku III BW tentang Perikatan. Pasal 1319 BW membedakan perjanjian menjadi perjanjian bernama (nominaat) dan perjanjian tidak bernama (innominaat). Adapun lelang dikatagorikan sebagai perjanjian bernama (nominaat) atau perjanjian khusus (benoemd) karena mempunyai nama tersendiri yaitu lelang. ${ }^{6}$

Lelang mengandung unsur-unsur yang tercantum dalam defenisi jual beli, yaitu adanya subjek hukum, yaitu penjual dan pembeli, adanya kesepakatan antara penjual dan pembeli tentang barang dan harga; adanya hak dan kewajiban

\footnotetext{
${ }^{5}$ M. Yahya Harahap, Ruang Lingkup Permasalahan Eksekusi Bidang Perdata (Gramedia 1994).[115].

${ }^{6}$ Fifidiana, “Kompetensi Badan Peradilan Umum dan Peradilan Tata Usaha Negara dalam Gugatan Pembatalan Risalah Lelang Studi Kasus Willem Irianto vs Bank Internasional Indonesia dan Willem Irianto vs Kepala Kantor Lelang Kelas II Kediri" (Tesis Magister Kenotariatan Universitas Indonesia 2009).[17].
} 
yang timbul antara pihak penjual dan pembeli. Oleh karenanya, penjualan lelang tidak boleh bertentangan dengan asas atau ajaran umum yang terdapat dalam hukum perdata, seperti ditegaskan dalam Pasal 1319 BW.

Vendu Reglement (selanjutnya disingkat "VR") yang masih berlaku sebagai dasar hukum lelang, menyatakan:

"Penjualan umum adalah pelelangan atau penjualan barang-barang yang dilakukan kepada umum dengan harga penawaran yang meningkat atau menurun atau dengan pemasukan harga dalam sampul tertutup, atau kepada orang-orang yang diundang atau sebelumnya diberitahu mengenai pelelangan atau penjualan itu, atau diizinkan untuk ikut serta, dan diberi kesempatan untuk menawar harga, menyetujui harga yang ditawarkan atau memasukkan harga dalam sampul tertutup".

Pelaksanaan lelang secara online sebagai salah satu cara penjualan melalui media elektronik/ internet, maka pengaturanya juga merujuk pada Peraturan Pemerintah Nomor 80 tahun 2019 Tentang Perdagangan Melalui Sistem Elektronik (selanjutnya disingkat “PP PMSE"), dimana Pasal 1 angka 1-nya menyebutkan bahwa : Perdagangan adalah tatanan kegiatan yang terkait dengan transaksi Barang dan/atau Jasa di dalam negeri dan melampaui batas wilayah negara dengan tujuan pengalihan hak atas Barang dan/atau Jasa untuk memperoleh imbalan atau kompensasi". Berdasarkan hal tersebut, maka pelaksanaan lelang secara online juga harus tunduk pada PP PMSE ini.

Dalam pelaksanaan lelang, ada 2 cara penawaran secara tertulis tanpa kehadiran peserta lelang melalui internet, yaitu melalui penawaran terbuka (open bidding) dan penawaran tertutup (closed bidding). Adapun penyampaian penawaran lelang tanpa kehadiran peserta berdasarkan Pasal 63 ayat (4) PMK/2020 tentang Petunjuk Pelaksanaan Lelang dilakukan melalui:

a. Surat tromol pos;

b. Surat elektronik (e-mail);

c. Aplikasi Lelang dengan penawaran terbuka (open bidding) atau penawaran tertutup closed bidding); atau

d. Platform e-Marketplace Auction.

Peserta lelang yang melakukan penawaran dengan harga tertinggi atau melampaui nilai nimit yang telah ditentukan oleh penjual/ pemilik barang itulah yang dinyatakan sebagai pemenang lelang. 
Adapun penyelenggara lelang menurut Pasal 7 PMK 213/2020 tentang Petunjuk Pelaksanaan Lelang, terdiri dari :

a. KPKNL; (semua jenis lelang atas permintaan penjual);

b. Balai Lelang (lelang non eksekusi sukarela atas permohonan penjual); dan

c. Kantor Pejabat Lelang Kelas II (lelang non eksekusi sukarela atas permohonan penjual atau Balai Lelang selaku kuasa dari penjual).

Dalam lelang, ada 5 asas yang menjadi dasar pelaksanaan lelang, antara lain : asas keterbukaan (transparansi), asas persaingan (competition), asas keadilan, asas kepastian hukum, asas efisiensi, dan asas akuntabilitas. ${ }^{7}$

Asas keterbukaan menghendaki agar seluruh lapisan masyarakat mengetahui adanya rencana lelang dan mempunyai kesenangan yang sama untuk mengikuti lelang sepanjang tidak dilarang oleh undang-undang. Oleh karena itu setiap pelaksanaan lelang harus didahului pengumuman lelang. ${ }^{8}$

Asas persaingan mengandung makna bahwa dalam proses pelaksanaan lelang setiap peserta atau penawar diberikan kesempatan yang sama untuk bersaing dalam mengajukan penawaran harga tertinggi atau setidaknya mencapai dan/ atau melampaui nilai limit dari barang yang akan dilelang dan ditetapkan oleh penjual atau pemilik barang. Pada dasarnya penawar tertinggi dari barang yang akan dilelang disahkan oleh pejabat lelang sebagai pembeli lelang. ${ }^{9}$

Asas keadilan mengandung pengertian bahwa pada saat proses lelang dilaksanakan harus dapat memenuhi rasa keadilan secara proporsional bagi setiap pihak yang berkepentingan. Asas ini untuk mencegah terjadinya keberpihakan Pejabat Lelang kepada peserta lelang tertentu atau berpihak hanya pada kepentingan penjual. Khusus pada pelaksanaan lelang eksekusi, penjual tidak boleh menentukan harga limit secara sewenang-wenang yang berakibat merugikan pihak tereksekusi. ${ }^{10}$

Asaskepastian hukummenghendakiagarlelangyang telahdilaksanakanakan

\footnotetext{
${ }^{7}$ H.Sudiarto, Pengantar Hukum Lelang Indonesia (Kencana 2021).[128].

8 ibid.

${ }^{9}$ ibid.

10 ibid.
} 
menjamin adanya perlindungan hukum bagi pihak-pihak yang berkepentingan dalam pelaksanaan lelang. Setiap pelaksanaan lelang dengan dibuat risalah lelang oleh pejabat lelang yang merupakan akta otentik. Risalah lelang oleh pejabat lelang yang merupakan akta autentik. Risalah lelang digunakan penjual/pemilik barang, pembeli dan pejabat lelang untuk mempertahankan dan melaksanakan hak dan kewajibannya. ${ }^{11}$

Asas efisiensi akan menjamin pelaksanaan lelang dilakukan dengan cepat dan biaya yang relatif murah karena lelang dilakukan pada tempat dan waktu yang telah ditentukan dan pembeli disahkan pada saat itu juga. ${ }^{12}$

Asas akuntabilitas menghendaki agar lelang yang dilaksanakan oleh pejabat lelang dapat dipertanggungjawabkan kepada semua pihak yang berkepentingan. Pertanggungjawaban pejabat lelang meliputi administrasi lelang dan pengelolaan uang lelang. ${ }^{13}$

\section{Keabsahan Pelaksanaan Lelang Non Eksekusi Sukarela Secara Online Tanpa Pejabat Lelang.}

Dalam suatu pelaksanaan lelang, diperlukan seorang Pejabat Lelang yang berfungsi sebagai pemimpin lelang, yangmana ia memiliki tugas dan tanggung jawab terhadap pelaksanaan lelang yang ia lakukan. Pejabat Lelang merupakan salah satu unsur penting dalam pelaksanaan lelang sebagaimana disebutkan dalam Pasal 21 PMK 213/2020 juncto Pasal 1a VR, yang menyatakan bahwa : “Setiap pelaksanaan lelang harus dilakukan oleh dan/ atau di hadapan Pejabat Lelang, kecuali ditentukan lain oleh Undang-Undang atau Peraturan Pemerintah".

Adapun pengecualian terhadap lelang yang dapat dilakukan tanpa pejabat lelang dapat ditemukan pada Pasal 49 VR, antara lain:
a. Lelang barang gadai;
b. Lelang ikan segar TPI;
c. Lelang kayu kecil dan hasil hutan pemerintah;

\footnotetext{
${ }^{11}$ ibid.[128-129].

12 ibid.[129].

${ }^{13}$ ibid.
} 
d. Lelang hasil tanah dan perkebunan yang ditanam diatas biaya penduduk Indonesia;

e. Lelang harta peninggalan tentara, Angkatan Laut pemerintah;

f. Lelang senjata api, obat bius dan keperluan perang.

Pasal 1 ayat (3) PMK 213/2020 menyebutkan bahwa yang dimaksud Pejabat Lelang adalah "orang yang berdasarkan peraturan perundang-undangan diberi wewenang khusus untuk melaksanakan Lelang". Dalam PMK tersebut, Pejabat lelang dibagi menjadi dua yaitu Pejabat Lelang Kelas I dan Pejabat Lelang Kelas II. Dalam Lelang Non Eksekusi Sukarela, Pejabat Lelang yang berwenang adalah Pejabat Lelang Kelas II.

Dalam hal pelaksanaan lelang secara online terdapat gangguan teknis, maka kedudukan pejabat lelang kelas II adalah sebagai pengatur yang memiliki kewajiban sesuai Pasal 74 ayat (1) PMK 213/2020, yaitu : “Dalam hal terdapat Gangguan Teknis dalam pelaksanaan lelang dengan penawaran melalui Aplikasi Lelang atau Platform e-Marketplace Auction, Pejabat Lelang berwenang mengambil tindakan:

a. Membatalkan lelang, jika Gangguan Teknis tidak dapat ditanggulangi hingga jam kerja berakhir pada hari pelaksanaan lelang; atau

b. Melaksanakan lelang setelah Gangguan Teknis dapat ditanggulangi sebelum jam kerja berakhir pada hari pelaksanaan lelang".

Secara umum, lelang adalah jual beli yang dilakukan dengan menawarkan barang secara terbuka untuk umum, oleh karena itu, maka pengaturan mengenai lelang tidak lepas dari ketentuan jual beli dalam Bab III BW tentang perikatan, termasuk lelang secara online. Lelang sebagai salah satu bentuk perjanjian bernama (nominaat) atau perjanjian khusus (benoemd), maka harus memperhatikan syarat sahnya perjanjian sebagaimana diatur dalam Pasal 1320 BW. Pasal 1320 BW merupakan instrumen pokok untuk uji keabsahan kontrak yang dibuat para pihak. Terdapat empat syarat yang harus dipenuhi untuk sahnya suatu kontrak, yaitu: ${ }^{14}$

\footnotetext{
${ }_{14}$ Agus Yudha Hernoko, Hukum Perjanjian Asas Proporsionalitas dalam Kontrak Komersial (Kencana 2010).[157].
} 
1. Sepakat mereka yang mengikatkan dirinya;

2. Kecakapan untuk membuat perikatan;

3. Suatu hal tertentu;

4. Suatu sebab yang halal atau diperbolehkan.

Dalam suatu pelaksanaan lelang, kehadiran seorang pejabat lelang memiliki peran penting, salah satunya untuk membuat Risalah Lelang. Pasal 1 angka 32 PMK 213/2020 menyebutkan bahwa Risalah Lelang adalah “berita acara pelaksanan lelang yang dibuat oleh Pejabat Lelang yang merupakan akta autentik dan mempunyai kekuatan pembuktian sempurna".

Suatu pelaksanaan lelang non eksekusi sukarela yang dilakukan secara online tanpa adanya seorang pejabat lelang, maka otomatis tidak ada risalah lelangnya. Akan tetapi, karena lelang tersebut dilakukan secara elektronik/ online tanpa pejabat lelang, maka alat bukti sebagai pengganti risalah lelang adalah berupa bukti transaksi. Bukti transaksi tersebut otomatis harus dibuat dalam bentuk elektronik, dimana Pasal 28 PP PMSE menyebutkan bahwa. bukti transaksi elektronik merupakan alat bukti yang sah dan mengikat para pihak.

Mengacu pada ketentuan Pasal 28 PP PMSE tersebut, Pasal 5 Undangundang Nomor 19 Tahun 2016 tentang Perubahan Atas Undang-Undang Nomor 11 Tahun 2008 tentang Informasi dan Transaksi Elektronik (selanjutnya disingkat “UU ITE") menyebutkan bahwa:

(1) Informasi Elektronik dan/atau Dokumen Elektronik dan/atau hasil cetaknya merupakan alat bukti hukum yang sah.

(2) Informasi Elektronik dan/atau Dokumen Elektronik dan/atau hasil cetaknya sebagaimana dimaksud pada ayat (1) merupakan perluasan dari alat bukti yang sah sesuai dengan Hukum Acara yang berlaku di Indonesia.

(3) Informasi Elektronik dan/atau Dokumen Elektronik dinyatakan sah apabila menggunakan Sistem Elektronik sesuai dengan ketentuan yang diatur dalam Undang-Undang ini.

(4) Ketentuan mengenai Informasi Elektronik dan/atau Dokumen Elektronik sebagaimana dimaksud pada ayat (1) tidak berlaku untuk :

a) Surat yang menurut Undang-Undang harus dibuat dalam bentuk tertulis; dan;

b) Surat beserta dokumennya yang menurut Undang-Undang harus dibuat dalam bentuk akta notaril atau akta yang dibuat oleh pejabat pembuat akta. 
164 | Vina Putri dan Bambang Sugeng: Keabsahan Lelang Non...

Selain itu, suatu bukti transaksi PMSE dapat dijadikan sebagai alat bukti lain dalam hukum acara dan tidak dapat ditolak sebagai alat bukti dala persidangan hanya karena bentuknya yang elektronik, serta bukti transaksi tersebut dapat dijadikan sebagai bukti tulisan yang autentik, jika menggunakan tanda tangan elektronik yang didukung oleh suatu sertifikat elektronik yang terpercaya sesuai dengan ketentuan peraturan perundang-undangan sebagaimana diatur pada Pasal 29 PP PMSE.

Berdasarkan ketentuan-ketentuan di atas, maka dapat disimpulkan bahwa pelaksanaan lelang non eksekusi sukarela secara online atau elektronik, bisa saja dilakukan tanpa kehadiran pejabat lelang, selama syarat-syarat perjanjian tersebut terpenuhi dan lelang yang dilakukan adalah lelang non eksekusi sukarela, serta keabsahan suatu informasi/ dokumen elektronik/ bukti transaksi terkait lelang non eksekusi sukarela secara online yang dilakukan tanpa adanya pejabat lelang, akan tetap dianggap sah sepanjang informasi yang tercantum di dalamnya dapat diakses, ditampilkan, dijamin keutuhannya, dan dapat dipertanggungjawabkan.

Esensi dari proses lelang adalah barang dan harga, sehingga harga dan barang merupakan unsur penting dalam proses lelang, termasuk juga untuk lelang non eksekusi sukarela secara online. Pengertian mengenai Harga Lelang diatur pada Pasal 1 angka 26 PMK 213/2020, yaitu harga penawaran tertinggi yang diajukan oleh Peserta Lelang yang telah disahkan sebagai pemenang lelang oleh pejabat lelang. Berkaitan dengan harga lelang, maka perlu diketahui juga mengenai nilai limit dalam pelaksanaan lelang.

Pengertian nilai limit diatur dalam Pasal 1 angka 25 PMK 213/2020, yaitu nilai minimal barang yang akan dilelang dan ditetapkan penjual. Nilai limit ini ditetapkan berdasarkan penilaian yang dapat dipertanggungjawabkan oleh penjual atau pemilik. Akan tetapi, Pasal 47 ayat (3) PMK 213/2020 memberikan pengecualian, dimana khusus untuk jenis Lelang Non Eksekusi Sukarela atas barang bergerak milik perorangan atau badan hukum atau badan usaha swasta, tidak diharuskan adanya Nilai Limit, kecuali ada permintaan dari penjual/ pemilik barang. 
Pada dasarnya dalam lelang non eksekusi sukarela, yang menetapkan nilai limit adalah pemilik barang lelang, dan bebas dalam penentuannya sebagaimana ditegaskan pada Pasal 48 ayat (1) huruf c PMK 213/2020, bahwa harga dapat ditentukan berdasarkan perkiraan sendiri atau ditetapkan oleh Pemilik Barang berdasarkan hasil penilaian dari penilai. Berdasarkan ketentuan ini maka dapat disimpulkan bahwa dalam pelaksanaan lelang non eksekusi sukarela/ lelang sukarela secara online tidak mengharuskan adanya suatu nilai limit, kecuali apabila penjual/ pemilik barang menghendakinya, maka dapat dilakukan dengan perkiraan sendiri (penjual).

\section{Perlindungan Hukum Para Pihak Apabila Terjadi Wanprestasi Lelang Non Eksekusi Sukarela Secara Online Tanpa Pejabat Lelang.}

Lelang sebagaimana telah dibahas sebelumnya, merupakan salah satu bentuk perjanjian dan diklasifikasikan sebagai perjanjian jual beli. Dalam kegiatan jual beli ataupun lelang secara online/ elektronik, diperlukan adanya kejujuran dan juga keterbukaan atau yang biasa disebut "iktikad baik", sebagaimana disebutkan dalam Pasal 37 PP PMSE bahwa "Pelaku usaha dalam melakukan penawaran secara elektronik kepada pihak lain harus dilakukan berdasarkan iktikad baik".

Pengertian iktikad baik dapat didefinisikan sebagai jujur atau kejujuran. ${ }^{15}$ Hal ini sangat diperlukan mengingat bahwa banyaknya kasus sebagai akibat dari adanya pihak yang melupakan kewajibannya dari yang telah diperjanjikan di awal atau biasa kita sebut dengan wanprestasi. ${ }^{16}$

Wanprestasi merupakan terminologi dalam hukum perdata yang artinya ingkar janji (tidak menepati janji), yang diatur dalam buku ke III BW. Wanprestasi harus didasari adanya suatu perjanjian, baik perjanjian tersebut dibuat secara lisan maupun tertulis, baik dalam bentuk perjanjian di bawah tangan maupun dalam akta autentik. Seseorang tidak dapat dinyatakan wanprestasi, jika ia tidak terikat

\footnotetext{
${ }^{15}$ Made Ray Adityanata, ‘Upaya Memperoleh Kepastian Hukum Demi Hak Dari Pemenang Suatu Lelang' (2020) 8 Jurnal Kertha Semaya Universitas Udayana.[2].

16 ibid.
} 
dalam suatu hubungan kontraktual. ${ }^{17}$

Adapun penggolongan wanprestasi dapat berupa: ${ }^{18}$

a. Tidak melakukan apa yang disanggupi akan dilakukan;

b. Melakukan apa yang dijanjikan, tetapi tidak sebagaimana dijanjikan;

c. Melakukan apa yang dijanjikan tetapi terlambat;

d. Melakukan sesuatu yang menurut perjanjian tidak boleh dilakukannya.

Wanprestasi dianggap sebagai suatu kegagalan untuk melaksanakan prestasi/janji yang telah disepakati disebabkan salah satu pihak tidakmelaksanakan kewajiban tanpa alasan yang dapat diterima. ${ }^{19}$ Tidak terpenuhinya suatu prestasi dapat mengakibatkan kerugian bagi pihak yang tidak mendapatkan hak-haknya yang disebabkan oleh pihak lain tidak memenuhi prestasinya, sehingga pihak yang dirugikan dapat menuntut ganti rugi atas perbuatan wanprestasi / ingkar janji tersebut. Adapun dalam hal debitur melakukan wanprestasi, kreditur dapat menuntut: ${ }^{20}$
a. Pemenuhan perjanjian;
b. Pembatalan perjanjian;
c. Ganti rugi;
d. Pemenuhan perjanjian dengan ganti rugi;
e. Pembatalan perjanjian dengan ganti rugi.

Pasal 1 angka 36 PMK 213/2020 menyebutkan, “Wanprestasi adalah suatu keadaan saat pembeli tidak melunasi kewajiban pembayaran lelang dalam jangka waktu yang telah ditentukan".

Perlindungan hukum sangat berkaitan erat dengan tanggung jawab. Pertanggungjawaban hukum muncul karna adanya perbuatan hukum yang menimbulkan suatu akibat hukum. Dalam hukum perdata, perbuatan hukum pada hakekatnya dikaitkan dengan perjanjian. Perjanjian adalah perbuatan hukum berdasarkan kata sepakat untuk menimbulkan suatu akibat hukum, sehingga

17 Yohanes Sogar Simamora, ‘Prinsip Transparansi dan Akuntabilitas dalam Kontrak Pemerintah Indonesia' Dalam pidato pengukuhan Guru Besar dalam Bidang Ilmu Hukum Perdata Fakultas Hukum Universitas Airlangga Surabaya, (2008).[10].

${ }^{18}$ R.Subekti dan R.Tjitrosudibio, Hukum Perjanjian (Intermasa 2005).[45].

${ }^{19}$ Burhan Sidabariba, Lelang Eksekusi Hak Tanggungan: Meniscayakan Perlindungan Hukum bagi Para Pihak (Papas Sinar Sinanti 2019).[111].

20 ibid. [19]. 
dapat dikatakan perjanjian merupakan hubungan hukum antara dua pihak atau lebih berdasarkan kata sepakat untuk menimbulkan suatu akibat hukum. ${ }^{21}$

Pertanggungjawaban para pihak terkait pelaksanaan lelang secara online dapat dijabarkan antara lain sebagai berikut:

\section{- Pertanggungjawaban Penyedia Platform e-Marketplace Auction.}

Platform e-Marketplace Auction berperan sebagai tempat/ wadah yang mempertemukan pihak penjual dan pihak pembeli dengan menyediakan sarana berupa wadah/ platform tersebut. Pihak penyedia platforme-Marketplace Auction memiliki peran dan tanggung jawab atas kerugian yang dialami baik oleh pihak penjual ataupun pihak pembeli. Akan tetapi, tidak semua platform e-Marketplace Auction mau bertanggung jawab atas segala resiko yang terjadi antara penjual dan pembeli. Dalam praktiknya, bentuk sanksi-sanksi bagi situs lelang yang wanprestasi pada transaksi lebih banyak berupa sanksi moral, seperti pemberian respon negatif pada fasilitas umpan balik, pemblokiran situs/aplikasi secara permanen, dan lain-lain.

Adapun syarat yang harus dipenuhi oleh pihak penyedia Platform e-Marketplace Auction sebagaimana diatur dalam Pasal71 ayat (3) PMK213/2020 bahwa harus terdaftar sebagai anggota asosiasi e-commerce Indonesia; dan menggunakan alamat domain situs web dan aplikasi yang memiliki sertifikat kelaikan sistem elektronik sesuai ketentuan perundang-undangan.

Pertanggungjawaban Platforme-Marketplace Auction sebagai penyelenggara lelang non eksekusi sukarela secara online diatur dalam Pasal 38 UU ITE yang menentukan bahwa:

(1) Setiap Orang dapat mengajukan gugatan terhadap pihak yang menyelenggarakan Sistem Elektronik dan/atau menggunakan Teknologi Informasi yang menimbulkan kerugian.

(2) Masyarakat dapat mengajukan gugatan secara perwakilan terhadap pihak yang menyelenggarakan Sistem Elektronik dan/atau menggunakan 
Teknologi Informasi yang berakibat merugikan masyarakat, sesuai dengan ketentuan Peraturan Perundang-undangan.

Berdasarkan Pasal 38 UU ITE tersebut, maka dapat diambil kesimpulan bahwa dalam hal terjadi kerugian pada saat transaksi tersebut dilakukan pada Platform e-Marketplace Auction bersangkutan, maka baik pihak penjual/ pemilik barang maupun pembeli/ pemenang lelang, dapat mengajukan gugatan kepada penyedia Platform e-Marketplace Auction tersebut, termasuk kerugian yang disebabkan dari wanprestasi dari pihak penyedia Platform e-Marketplace Auction, sehingga risiko terkait transaksi lelang antara penjual/ pemilik barang dengan pembeli/ pemenang lelang yang menimbulkan kerugian dari wanprestasi tersebut menjadi tanggung jawab dari penyedia Platform e-Marketplace Auction. Dengan demikian kepastian hukum dan perlindungan hukum bagi para pihak yang mengadakan transaksi lelang kiranya dapat terjamin.

Mengenai sanksi bagi pihak penyedia Platform e-Marketplace Auction yang melakukan wanprestasi dapat dilihat pada ketentuan Pasal 109 Ayat (2) PMK 213/2020 yang menyebutkan bahwa :

(3) Dalam hal jual beli dengan cara Lelang yang dilakukan melalui Aplikasi Lelang atau Platform e-Marketplace Auction, pihak lain sebagaimana dimaksud pada ayat (1) dalam waktu 3 (tiga) bulan setelah tanggal surat peringatan tetap tidak memenuhi ketentuan peraturan perundangundang di bidang Lelang, Direktur Jenderal atas nama Menteri dapat meminta kepada kementerian yang membawahi bidang komunikasi dan informatika untuk memberikan sanksi sesuai ketentuan peraturan perundang-undangan.

Akan tetapi, berdasakan ketentuan yang diatur dalam PMK 213/2020, tidak dibahas secara tegas mengenai sanksi bagi penyedia platform e-Marketplace Auction. Oleh karenanya, kembali melihat pada lelang non eksekusi sukarela ini dilakukan melalui media elektronik (online) maka, pengaturan mengenai sanksinya dapat dilihat berdasarkan ketentuan Pasal 80 ayat (2) PP PMSE yang mengatur sanksi administratif bagi pihak penyedia platform e-Marketplace Auction, dapat berupa: 
a. Peringatan tertulis;

b. Dimasukkan dalam daftar prioritas pengawasan;

c. Dimasukkan dalam daftar hitam;

d. Pemblokiran sementara layanan PPMSE dalam negeri dan/ atau PPMSE luar negeri oleh instansi terkait yang berwenang; dan/atau

e. Pencabutan izin usaha.

\section{- Pertanggungjawaban Penjual/ Pemilik Barang.}

Pertanggungjawaban penjual/pemilik barang lelang non eksekusi sukarela secara online dapat terjadi karena ada kemungkinan wanprestasi, diantaranya:

1. Tidak mengirim barang;

2. Mengirim barang tetapi tidak tepat waktu;

3. Mengirimkan barang yang kondisinya tidak sesuai dengan yang telah disepakati;

4. Mengirimkan barang kepada pemenang lelang tepat pada waktunya, namun barang yang dikirimkan tidak sesuai denga napa yang disepakati, barang tersebut ternyata memiliki cacat tersembunyi yang tidak diinformasikan oleh penjual.

Tindakan wanprestasi membawa konsekuensi terhadap timbulnya hak pihak yang dirugikan untuk menuntut pihak yang melakukan wanprestasi untuk memberikan ganti rugi, oleh karenanya, transaksi elektronik yang dilakukan oleh para pihak wajib didasari dengan iktikad baik. Hal ini bertujuan agar pembeli/ pemenang lelang bisa mendapatkan haknya, yaitu mendapatkan kepastian atas barang yang dimenangkannya dalam pelelangan tersebut.

Tuntutan yang dapat dilakukan pembeli atas kelalaian penjual adalah, pembeli dapat menuntut pembatalan transaksi sebagaimana yang diatur dalam Pasal 1480 BW, selanjutnya menurut ketentuan-ketentuan Pasal 1266 BW bahwa: "Syarat batal dianggap selalu dicantumkan dalam persetujuan yang timbal balik, andaikata salah satu pihak tidak memenuhi kewajibannya". Hal ini berkaitan pula dengan Pasal 1267 BW, yaitu bahwa: 
"Pihak yang terhadapnya perikatan tidak dipenuhi, dapat memilih; memaksa pihak yang lain untuk memenuhi persetujuan, jika hal itu masih dapat dilakukan, atau menuntut pembatalan persetujuan, dengan penggantian biaya, kerugian dan bunga".

Dalam hal demikian persetujuan tidak batal demi hukum, tetapi pembatalan harus dimintakan kepada Pengadilan. Permintaan ini juga harus dilakukan, meskipun syarat batal mengenai tidak dipenuhinya kewajiban dinyatakan di dalam persetujuan. Jika syarat batal tidak dinyatakan dalam persetujuan, maka Hakim dengan melihat keadaan, atas permintaan tergugat, leluasa memberikan suatu jangka waktu untuk memenuhi kewajiban, tetapi jangka waktu itu tidak boleh lebih dan satu bulan. ${ }^{22}$

Terhadap penjual/ pemilik barang yang melakukan wanprestasi, maka pembeli/ pemenang lelang dapat menuntut berdasarkan Pasal 1496 BW, yaitu:

1) Pembeli dapat menuntut pengembalian uang harga pembelian dari penjual,

2) Pembeli dapat menuntut pengembalian hasil-hasil yang diperoleh pembeli dari barang tersebut kepada penjual, apabila barang tersebut diambil oleh orang lain beserta hasil-hasil yang diperolehnya,

3) Pembeli dapat menuntut pebnggantian biaya-biaya yang telah dikeluarkannya untuk mengurus sengketa tersebut,

4) Pembeli juga dapat menuntut penggantian biaya, kerugian, dan bunga, serta biaya perkara mengenai pembelian dan penyerahan dalam perjanjian jual beli tersebut.

\section{- Pertanggungjawaban Pembeli/Pemenang Barang}

Pembeli/ pemenang lelang yang telah melakukan kewajibannya berupa pembayaran barang dan atau jasa, memiliki hak atas suatu prestasi dari penjualnya. Akan tetapi, jika pembeli/ pemenang lelang tersebut tidak melaksanakan kewajibannya atau memenuhi prestasinya kepada pihak penjual/ pemilik barang, maka ia dapat dikatakan telah melakukan wanprestasi. Pertanggungjawaban pembeli/pemenang lelang non eksekusi

${ }^{22}$ Stefanus Halim, 'Keabsahan Lelang Barang Milik Swasta Dengan Media Internet Ditinjau Dari Hukum Informasi Dan Transaksi Elektronik Dan Peraturan Lelang' (2015) 4 Calyptra : Jurnal Ilmiah Mahasiswa Universitas Surabaya.[34]. 
sukarela secara online dapat terjadi karena adanya kemungkinan wanprestasi yang dilakukannya, antara lain:

1. Tidak membayar sesuai yang disepakati;

2. Membayar tetapi tidak sesuai/ kurang dari yang disepakati;

3. Membayar tetapi jangka waktu tidak sesuai perjanjian/ telat;

4. Tidak membayar biaya kirim/ ongkir (dalam hal pengiriman ditanggung oleh pembeli/ pemenang lelang).

Pertanggungajwaban pembeli/ pemenang barang lelang non eksekusi sukarela secara online atas kemungkinan wanprestasi tersebut, didasarkan pada ketentuan Pasal 24 PMK 213/2020, yang menentukan: “Pembeli dilarang mengambil atau menguasai barang yang dibelinya sebelum memenuhi Kewajiban Pembayaran Lelang dan kewajiban lainnya yang sah sesuai peraturan perundang-undangan".

Selanjutnya, Pasal 81 PMK 213/2020 menentukan: "Dalam hal Pembeli tidak melunasi Kewajiban Pembayaran Lelang sebagaimana dimaksud dalam Pasal 80, pada hari kerja berikutnya Pejabat Lelang harus membatalkan pengesahannya sebagai Pembeli dengan membuat pernyataan pembatalan".

Pasal 78 ayat (1) PMK 213/2020 menyebutkan, dalam hal pembeli wanprestasi, maka peserta lelang yang mengajukan penawaran peringkat kedua dapat disahkan sebagai Pembeli; atau jika tidak bersedia, maka peserta lelang yang mengajukan penawaran peringkat ketiga dapat disahkan sebagai pembeli. Pembeli peringkat kedua ataupun ketiga tersebut baru akan disahkan setelah dilakukan pembatalan terhadap pembeli yang wanprestasi. Adapun pembatalan tersebut dilakukan tanpa mengindahkan ketentuan Pasal 1266 BW dan Pasal 1267 BW.

Pasal 45 ayat (2) PMK 213/2020 mengatur mengenai sanksi yang dapat diberikan terhadap pembeli/ pemenang lelang yang melakukan tindakan wanprestasi pada lelang non eksekusi sukarela, yaitu uang jaminan penawaran lelang menjadi milik pemilik barang seluruhnya sesuai kesepakatan; menjadi milik pemilik barang dan/atau Balai Lelang sesuai kesepakatan, pada jenis Lelang Noneksekusi Sukarela yang diselenggarakan oleh Balai Lelang bekerja 
sama dengan Pejabat Lelang Kelas II; atau menjadi milik pemilik barang dan/ atau Pejabat Lelang Kelas II sesuai kesepakatan, pada jenis Lelang Noneksekusi Sukarela yang diselenggarakan oleh Kantor Pejabat Lelang Kelas II.

Selain pembatalan pengesahan sebagai pembeli/ pemenang lelang dan uang jaminan penawaran lelang yang hangus, PMK 213/2020 menegaskan bahwa, penjual/ pemilik barang dapat menuntut ganti rugi atas kerugian yang timbul akibat dari wanprestasi yang dilakukan oleh pembeli/ pemenang lelang tersebut.

\section{Upaya Hukum Penyelesaian Sengketa Dalam Lelang Non Eksekusi Sukarela}

\section{Secara Online Tanpa Pejabat Lelang.}

Terkait wanprestasi dan pertanggungjawaban hukum para pihak tersebut, pada dasarnya dapat terjadi karena adanya suatu hubungan kontraktual/ perjanjian. Apabila terjadi suatu konflik/ sengketa antara para pihak maka hal tersebut harus segera diselesaikan.

Penyelesaian sengketa dalam masyarakat umumnya dibagi menjadi 2 (dua), yaitu melalui Litigasi dan/atau Non Litigasi. Litigasi artinya menyelesaikan sengketa di pengadilan. Sedangkan Non Litigasi atau disebut juga penyelesaian sengketa diluar pengadilan atau Alternatif Penyelesaian Sengketa (APS). ${ }^{23}$

Alternatif penyelesaian sengketa (APS) sebagaimana disebutkan dalam Pasal 1 angka 10 Undang-Undang Nomor 30 tahun 1999 tentang Arbitrase dan Alternatif Penyelesaian Sengketa (UU Arbitrase) adalah “lembaga penyelesaian sengketa atau beda pendapat melalui prosedur yang disepakati para pihak, yakni penyelesaian diluar pengadilan dengan cara konsultasi, negosiasi, mediasi, konsilasi, atau penilaian ahli",

Dalam pelaksanaan lelang secara online, penyelesaian sengketanya dapat didasarkan pada ketentuan Pasal 72 PP PMSE, yang mengatur bahwa:

(1) Dalam hal terjadi sengketa dalam PMSE, para pihak dapat menyelesaikan

${ }^{23}$ Henny Mono, Alternatif Penyelesaian Sengketa dan Mediasi (Bayumedia Publishing 2014).[2]. 
sengketa melalui pengadilan atau melalui mekanisme penyelesaian sengketa lainnya.

(2) Penyelesaian sengketa PMSE sebagaimana dimaksud ayat (1) dapat diselenggarakan secara elektronik (Online Dispute Resolution) sesuai dengan ketentuan peraturan perundang-undangan.

Kemudian, Pasal 74 PP PMSE menyebutkan bahwa :

(1) Para pihak memiliki kewenangan untuk menetapkan forum pengadilan, arbitrase, atau lembaga penyelesaian sengketa alternatif lainnya yang berwenang menangani sengketa yang mungkin timbul dari PMSE internasional yang dibuatnya.

(2) Dalam hal para pihak tidak melakukan pilihan forum sebagaimana dimaksud pada ayat (1), penetapan kewenangan pengadilan, arbitrase, atau lembaga penyelesaian sengketa alternatif lainnya yang berwenang menangani sengketa yang mungkin timbul dari transaksi tersebut, didasarkan pada asas Hukum Perdata Internasional.

(3) Dalam hal para pihak memilih menyelesaikan sengketa PMSE internasional melalui forum penyelesaian sengketa yang ada di Indonesia, maka lembaga yang berwenang menyelesaikan sengketa tersebut yaitu:

a. Pengadilan Negeri Jakarta Pusat; atau

b. Lembaga arbitrase atau alternatif penyelesaian sengketa lainnya, sesuai dengan ketentuan peraturan perundang-undangan.

Arbitrase adalah perjanjian perdata yang dibuat berdasarkan kesepakatan para pihak untuk menyelesaikan sengketa mereka yang diputuskan oleh pihak ketiga yang disebut arbiter yang ditunjuk secara bersama-sama oleh para pihak yang bersengketa dan para pihak menyatakan akan menaati putusan yang diambil oleh arbiter. ${ }^{24}$

Berdasarkan ketentuan-ketentuan di atas tersebut, maka dapat disimpulkan bahwa penyelesaian sengketa lelang non eksekusi sukarela yang dilakukan

${ }^{24}$ Rifqani Nur Fauziah Hanif (KPKNL Manado), “Arbitrase dan Alternatif Penyelesaian Sengketa" (DJKN, 2020) <https:// www.djkn.kemenkeu.go.id/kpknl-manado/baca-artikel/13628/ Arbitrase-Dan-Alternatif-Penyelesaian-Sengketa.html>. 
secara online, dapat dilakukan melalui pengadilan (litigasi), melalui mekanisme penyelesaian sengketa lainnya (non-litigasi), ataupun secara elektronik (online dispute resolution) sebagaimana diatur pada Pasal 72 PP PMSE di atas. Para pihak dapat memilih penyelesaian sengketa tersebut dilakukan dengan cara forum pengadilan, arbitrase, atau lembaga penyelesaian sengketa alternatif lainnya sesuai ketentuan peraturan perundang-undangan (Pasal 74 PP PMSE).

Online Dispute Resolution (ODR) merupakan suatu cara penyelesaian yang dilakukan melalui media internet, dalam arti bahwa proses penyelesaiannya dilakukan oleh para pihak yang berada dalam wilayah lintaws batas negara (borderless) tanpa harus bertemu muka (face to face). ${ }^{25}$ Pada dasarnya, penyelesaian dengan cara ODR sama seperti penyelesaian sengketa konvensional lainnya, perbedaannya hanya terletak pada medianya saja, yaitu dengan menggunakan internet. ODR sendiri masuk dalam katagori alternatif penyelesaian sengketa (APS) sebagaimana disebut dalam Pasal 1 angka 10 UU Arbitrase, dimana ada 3 (tiga) cara penyelesaian sengketanya, yaitu negosiasi online, mediasi online dan arbitrase online. ${ }^{26}$

Meskipun pengaturan mengenai Online Dispute Resolution (ODR) belum diatur secara tegas di dalam sistem hukum Indonesia, bukan berarti penyelesaian sengketa secara online tidak dapat dilakukan. Penyelesaian sengketa secara online tetap dapat diterapkan di Indonesia karena telah sesuai dan tidak bertentangan dengan peraturan perundang-undangan di Indonesia. Adapun kelebihan Online Dispute Resolution (ODR) sebagai penyelesaian sengketa dibandingkan dengan penyelesaian sengketa secara konvensional, antara lain: waktu dan mekanismenya lebih cepat dan efisien, murah, serta sederhana.

Dalam pelaksanaan lelang, terutama lelang yang dilakukan secara online, sengketa/ konflik yang kerap terjadi adalah peserta lelang/ calon pembeli yang telah diumumkan sebagai pemenang lelang, lalu melakukan wanprestasi (tidak

\footnotetext{
${ }^{25}$ Moch. Basarah, Prosedur Alternatif Penyelesaian Sengketa; Arbitrase Tradisional dan Modern (Online) (Genta Publishing 2011).[92].

${ }^{26}$ Made Widnyana, Alternatif Penyelesaian Sengketa dan Arbitrase (Fikahati Aneska 2014).[47].
} 
membayar sesuai kesepakatan, dll), maka sebelum menempuh suatu upaya hukum, penjual/ pemilik barang harus memberikan teguran atau pemberitahuan terlebih dahulu kepada pembeli/ pemenang lelang tersebut sebelum penjual/ pemilik barang ingin menuntut pemenuhan prestasi dari pembeli. Dalam ilmu hukum, upaya ini disebut somasi. Namun, apabila tetap tidak ada iktikad baik dari pembeli/ pemenang lelang yang telah melakukan wanprestasi tersebut, maka upaya hukum yang dapat ditempuh oleh penjual/ pemilik barang adalah dengan menempuh upaya sesuai dengan ketentuan Pasal 72 juncto Pasal 74 PP PMSE, sebagaimana disebutkan di atas.

Pada prinsipnya, peserta lelang/ calon pembeli dalam pelaksanaan lelang yang dilakukan secara online, harus diberikan perlindungan ketika mengikuti lelang tersebut sesuai dengan tata cara dan prosedur pelaksanaan lelang sampai dengan ditetapkannya seorang pembeli sebagai pemenang lelang dan menerima barang dengan kondisi yang baik sesuai dengan yang ada dalam pengumuman lelang, dengan catatan setelah ia melakukan kewajibannya sebagai pemenang lelang, yaitu melunasi harga sesuai yang disepakati dalam lelang tersebut.

Suatu obyek lelang yang tidak dikuasai secara penuh oleh pihak yang berhak, dapat menempuh upaya hukum dengan cara mengajukan gugatan ke Pengadilan Negeri setempat agar dilakukannya penindakan dengan cara pengosongan secara paksa terhadap obyek lelang yang secara hukum sudah dimenangkan melalui prosedur lelang. ${ }^{27}$

\section{Kesimpulan}

Keabsahan lelang non eksekusi sukarela secara online (Platform e-Marketplace Auction) tanpa adanya pejabat lelang adalah sah dan dapat mengikat para pihak, karena lelang juga merupakan perjanjian yang mengadopsi karakteristik dari perjanjian jual beli (Pasal 1457 BW), dan selama lelang tersebut telah memenuhi

${ }^{27}$ Mafita, “Pelaksanaan Lelang Melalui Internet Terhadap Aset Barang Milik Negara Pada Kantor Pelayanan Kekayaan Negara Dan Lelang Serang Berdasarkan Asas Kepastian Hukum" (2019) 2 Nurani Hukum: Jurnal Ilmu Hukum.[26-34]. 
syarat sahnya perjanjian menurut Pasal 1320 BW. Selain itu, keabsahan suatu informasi/dokumen elektronik terkait akan tetap dianggap sah sepanjang informasi yang tercantum di dalamnya dapat diakses, ditampilkan, dijamin keutuhannya, dan dapat dipertanggungjawabkan. Serta, PMK 213/2020 tentang petunjuk pelaksanaan lelang berlaku secara mutatis mutandis (dapat diterapkan jika dibutuhkan) terhadap pelaksanaan lelang yang dilakukan secara online sebagaimana lelang konvensional, dengan pengecualian pada cara penawaran dan kehadiran peserta lelang.

Perlindungan hukum para pihak adalah dengan melakukan upaya hukum penyelesaian sengketa, dimana para pihak dapat memilih penyelesaian baik melalui pengadilan, arbitrase ataupun lembaga penyelesaian sengketa alternatif lainnya (secara konvensional/ online dispute resolution) sesuai dengan ketentuan Peraturan Perundang-undangan.

\section{Daftar Bacaan}

\section{Buku}

Burhan Sidabariba, Lelang Eksekusi Hak Tanggungan: Meniscayakan Perlindungan Hukum bagi Para Pihak (Papas Sinar Sinanti 2019).

H.Sudiarto, Pengantar Hukum Lelang Indonesia (Kencana 2021).

Henny Mono, Alternatif Penyelesaian Sengketa dan Mediasi (Bayumedia Publishing 2014).

Hernoko AY, Hukum Perjanjian Asas Proporsionalitas dalam Kontrak Komersial (Kencana 2010).

M. Yahya Harahap, Ruang Lingkup Permasalahan Eksekusi Bidang Perdata (Gramedia 1994).

Made Widnyana, Alternatif Penyelesaian Sengketa dan Arbitrase (Fikahati Aneska 2014).

Mamudji SS dan S, Penelitian Hukum Normatif (Suatu Tinjauan Singkat) (Rajawali Pers 2001).

Moch. Basarah, Prosedur Alternatif Penyelesaian Sengketa; Arbitrase Tradisional dan 
Modern (Online) (Genta Publishing 2011).

Peter Mahmud Marzuki, Penelitian Hukum (Kencana Prenada Media Group 2016).

R.Subekti dan R.Tjitrosudibio, Hukum Perjanjian (Intermasa 2005).

Sudikno Mertokusumo, Mengenal Hukum suatu Pengantar (Liberty 1999).

\section{Jurnal}

Stefanus Halim, “Keabsahan Lelang Barang Milik Swasta Dengan Media Internet Ditinjau Dari Hukum Informasi Dan Transaksi Elektronik Dan Peraturan Lelang" (2015) 4 Jurnal Ilmiah Mahasiswa Universitas Surabaya 1.

Made Ray Adityanata, “Upaya Memperoleh Kepastian Hukum Demi Hak Dari Pemenang Suatu Lelang" (2020) 8 Jurnal Kertha Semaya Universitas Udayana.

Mafita, "Pelaksanaan Lelang Melalui Internet Terhadap Aset Barang Milik Negara Pada Kantor Pelayanan Kekayaan Negara Dan Lelang Serang Berdasarkan Asas Kepastian Hukum" (2019) 2 Nurani Hukum: Jurnal Ilmu Hukum.

Margono Dwi Susilo dan Mirza Prasetya, "Lelang dengan Platform e-Marketplace Auction Perbandingan antara eBay dan e-Auction (lelang.go.id)" (DJKN, 2019) <https://www.djkn.kemenkeu.go.id/artikel/baca/12812/Lelangdengan-Platform-e-Marketplace-Auction-Perbandingan-antara-eBay-dan-eAuction-lelanggoid.html> diakses 7 Januari 2021.

\section{Karya Ilmiah}

Fifidiana, "Kompetensi Badan Peradilan Umum dan Peradilan Tata Usaha Negara dalam Gugatan Pembatalan Risalah Lelang Studi Kasus Willem Irianto vs Bank Internasional Indonesia dan Willem Irianto vs Kepala Kantor Lelang Kelas II Kediri" (Tesis Magister Kenotariatan Universitas Indonesia 2009).

\section{Laman}

Margono Dwi Susilo dan Mirza Prasetya, "Lelang dengan Platform e-Marketplace Auction Perbandingan antara eBay dan e-Auction (lelang.go.id)" (DJKN, 2019) <https://www.djkn.kemenkeu.go.id/artikel/baca/12812/Lelangdengan-Platform-e-Marketplace-Auction-Perbandingan-antara-eBay-dan-eAuction-lelanggoid.html> diakses 7 Januari 2021.

Rifqani Nur Fauziah Hanif (KPKNL Manado), "Arbitrase dan Alternatif Penyelesaian Sengketa" (DJKN, 2020) https://www.djkn.kemenkeu.go.id/ 
178 | Vina Putri dan Bambang Sugeng: Keabsahan Lelang Non...

kpknl-manado/baca-artikel/13628/Arbitrase-Dan-Alternatif-PenyelesaianSengketa.html.

How to cite: Vina Putri Salim dan Bambang Sugeng Ariadi Subagyono, 'Keabsahan Lelang Non Eksekusi Sukarela Secara Online Tanpa Pejabat Lelang' (2022) Vol. 5 No. 1 Notaire. 